\title{
Analysis of implementation of ISO 9001:2015 in SME Aldin Natural Home
}

\author{
Naniek Utami Handayani ${ }^{1, *}$, Anita Mustikasari ${ }^{2, *}$, Sabrina Hutagalung ${ }^{1}$ and Baby Monica ${ }^{1}$ \\ ${ }^{1}$ Department of Industrial Engineering, Diponegoro University, Semarang, Indonesia 50275 \\ ${ }^{2}$ Department of Management, Yogyakarta State University, Yogyakarta, Indonesia 55281
}

\begin{abstract}
SME is required to improve their service quality and resource management for giving customer loyalty toward product offered. The ISO 9001 is one of quality management system standard which is approved globally which are frequently communicated thru service quality insurance to solve the matter of indistinct expectancy Aldin Natural Home is SME engaged in dolls production. In the implementation of quality management system, they have lack on standard operating procedure (SOP). This study aims to analyze and find out the readiness of ISO 9001:2015 implementations in SME Aldin Natural Home. Gap analysis method also is conducted in this research to describe the differences between required and actual quality management systems. The results are SME Aldin Natural Home need to understand and review of implementation of ISO 9001:2015 with the highest $29 \%$ on clause 8 , Operation while the lowest is $14 \%$ on clause 9, Performance Evaluation.
\end{abstract}

\section{Introduction}

In the globalization era, SME is required to improve their service quality and resource management for giving customer loyalty toward product offered. Therefore, product guarantee strategy is needed to gain customer trust.

The ISO 9001 is one of quality management system standard which is approved globally which are frequently communicated thru service quality insurance to solve the matter of indistinct expectancy $[1,2]$. More than one million organizations in 187 countries has implemented ISO 9001 standard, and a high number of these organizations purpose at attaining product innovation [3]. According to Gaspersz 2001, the ISO 9001 set up requirement and recommendation for design and assessment of quality management system that aims to ensure companies or SMEs give products (goods/ services) which meet the specified requirements [4]. ISO 9001 objective to increase customer satisfaction by means of the effective use of the system, including processes for continued improvement

A recent version of International Organization for Standardization (ISO) 9001 raise on September 2015, or it known as ISO 9001:2015. For the first time, requirements are released that have contents a responsibility towards organizations to ponder the organizational knowledge role as a resource. This details will oblige organization to consider all the phase of the knowledge management cycle systematically [5]. 
The differences between ISO 9001:2008 and ISO 9001:2015 located on risk management. In ISO 9001:2008, risk is considered exclude in system whilst in ISO 9001:2015, considered include in system.

Aldin Natural Home is SME engaged in dolls production. In the implementation of quality management system, they have lack on standard operating procedure (SOP). For instance, using old version of SOP however there are modification or addition products. Therefore, it is needed more detailed production record and further review to eliminate the lack between real work and SOP. In addition, it will support SME Aldin Natural Home to receive ISO 9001 certification.

This study aims to analyze and find out the readiness of ISO 9001:2015 implementations in SME Aldin Natural Home. Gap analysis method also be conducted in this research to describe the differences between required and actual quality management systems.

\section{Research Method}

Gap analysis is method that could identify discrepancy between ISO 9001 standard and SME organization process. Therefore, with that method, organization could take actions or strategies to eliminate lack that occur.

Gap analysis checklist is one of ways that simplify to analyze factors related ISO 9001 standard in form of checklist. Checklist is arranged by ISO 9001:2015 standard. In order to simplify analysis each clause so it is given assessment indicators in each clause as follow or shown on Figure 1:

Score 1 : The organization or SME does not understand what is required and does not do so.

Score 2 : The organization or SME understands the importance of the activity but does not do so.

Score 3 : The organization or SME has documents but has not been applied or done but not recorded.

Score 4 : The organization or SME is engaged in an activity but not consistent.

Score 5 : The organization or SME is doing well (done consistently).

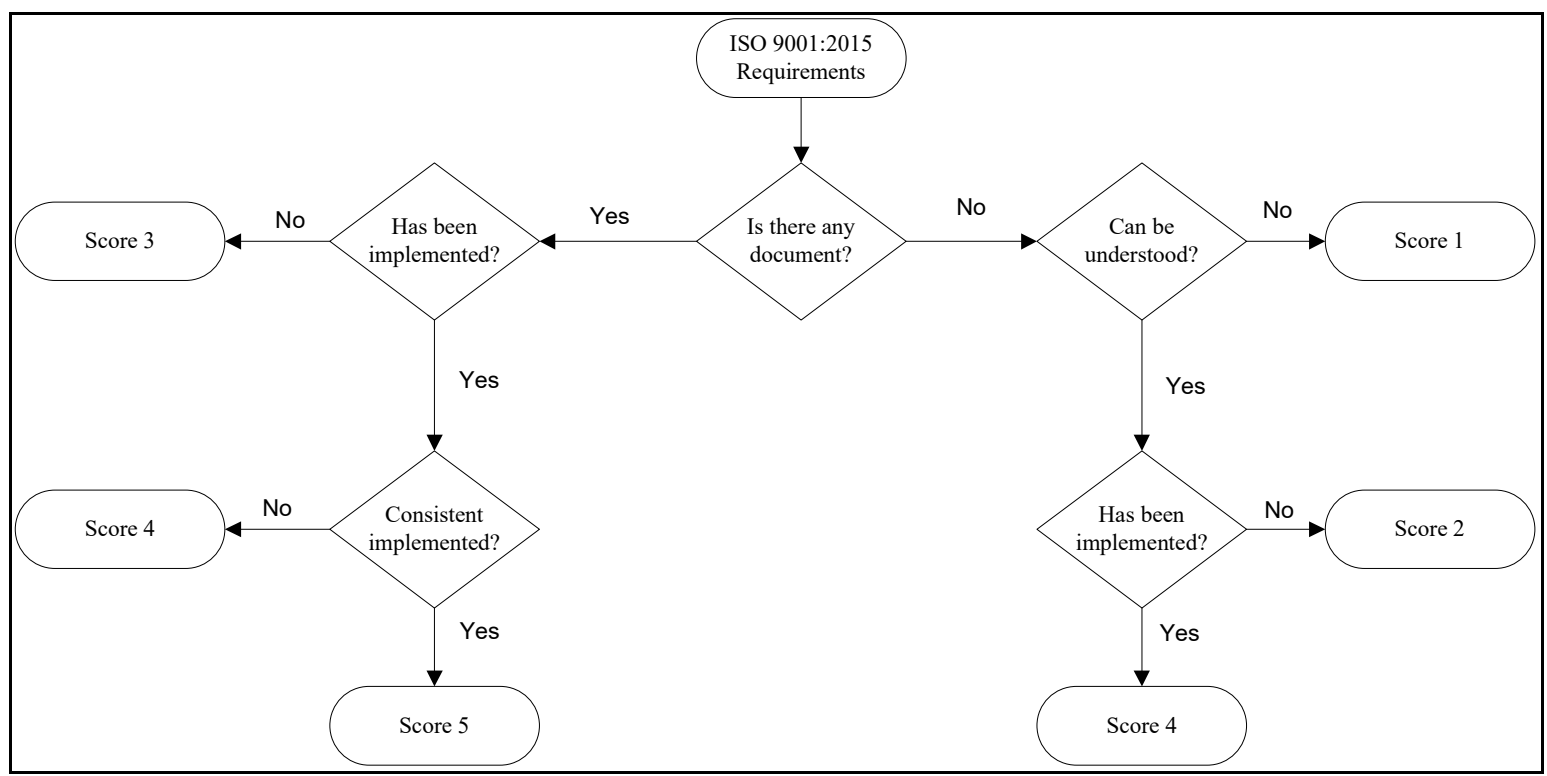

Fig. 1. Assessment Indicators 


\section{Results and Analysis}

\subsection{Analysis of Implementation ISO 9001:2015}

The ISO 9001: 2008 consists of 8 clauses, scope, normative references, terms and definitions, quality management system, management responsibility, resource management, product realization, measurement, analysis and improvement [6]. While the ISO 9001:2015 consists of 10 clauses, scope, normative references, terms and definitions, context of the organization, leadership, planning, support, operation, performance evaluation and improvement [7].

SME Aldin Natural Home has not been implemented ISO 9001:2015. So, this research assesses readiness of SME Aldin Natural Home in implementation of ISO 9001:2015 using questionnaire as shown on Table 1.

Table 1. Questionnaire Result Related on ISO 9001:2015 Clauses SME Aldin Natural Home

\begin{tabular}{|c|l|c|c|c|}
\hline No Clause & \multicolumn{1}{|c|}{ Clause } & Score & Maximum Score & Percentage \\
\hline 4 & Context of the Organization & 5 & 20 & $25 \%$ \\
\hline 5 & Leadership & 4 & 15 & $27 \%$ \\
\hline 6 & Planning & 3 & 15 & $20 \%$ \\
\hline 7 & Support & 7 & 25 & $28 \%$ \\
\hline 8 & Operation & 10 & 35 & $29 \%$ \\
\hline 9 & Performance Evaluation & 2 & 15 & $14 \%$ \\
\hline 10 & Improvement & 3 & 15 & $20 \%$ \\
\hline
\end{tabular}

From the assessment results can be seen the implementation of ISO 9001: 2015 with range as shown Table 2. It shows that SME Aldin Natural Home is in range $14 \%$ to $29 \%$ so it needs to understand and review of implementation of ISO 9001:2015 because there are many lacks of standard.

Table 2. Range Assessment Result

\begin{tabular}{|l|l|}
\hline Percentage & \multicolumn{1}{|c|}{ Details } \\
\hline $100 \%$ & Ready for implementing ISO 9001:2015 \\
\hline $91 \%-99 \%$ & $\begin{array}{l}\text { Ready for implementing ISO 9001:2015 but there are several work procedures } \\
\text { inconsistent }\end{array}$ \\
\hline $76 \%-90 \%$ & $\begin{array}{l}\text { Ready for implementing ISO 9001:2015 but there are several work processes has not } \\
\text { proceed }\end{array}$ \\
\hline $51 \%-75 \%$ & Many work procedures has not executed but has been implemented ISO 9001:2015 \\
\hline $0 \%-50 \%$ & $\begin{array}{l}\text { Company or SME needs to understand and review of implementation of ISO } \\
9001: 2015 \text { because there are many lacks of standard. }\end{array}$ \\
\hline
\end{tabular}




\subsection{Analysis of Obstacles of ISO 9001:2015 Implementation}

Several obstacles faced by SME Aldin Natural Home in implementing of ISO 9001:2015 shown on Table 3.

Table 3. Obstacles Related on ISO 9001:2015 Clauses SME Aldin Natural Home

\begin{tabular}{|c|c|c|}
\hline $\begin{array}{c}\text { No } \\
\text { Clause }\end{array}$ & Sub-Clause & Obstacles \\
\hline 4 & $\begin{array}{l}\text { 4.1 Understanding context of } \\
\text { organization } \\
4.4 \text { Quality management } \\
\text { system and their processes }\end{array}$ & $\begin{array}{l}\text { 1. Lack of understanding to define issues related } \\
\text { with SME. } \\
\text { 2. Has not had criteria and method that needed to } \\
\text { ensure effective operation. }\end{array}$ \\
\hline 5 & $\begin{array}{l}5.1 \text { Leadership and } \\
\text { commitment } \\
5.2 \text { Policy }\end{array}$ & $\begin{array}{l}\text { 1. Lack of commitment to do controlling toward } \\
\text { management system } \\
\text { 2. Lack of job desk because of less communication } \\
\text { among top management. }\end{array}$ \\
\hline 6 & $\begin{array}{l}6.1 \text { Action to overcome risk } \\
\text { and opportunity } \\
6.2 \text { Quality objective and } \\
\text { planning to reach it }\end{array}$ & $\begin{array}{l}\text { 1. There is no planning to resolve risk, even SME } \\
\text { has less attention toward the bad impact that will } \\
\text { occur on production process } \\
\text { 2. Lack of consistency on reach their target }\end{array}$ \\
\hline 7 & $\begin{array}{l}\text { 7.1 Resources } \\
\text { 7.2 Documented information }\end{array}$ & $\begin{array}{l}\text { 1. It has limited time because only has few } \\
\text { competent employees } \\
\text { 2. Limited facilities }\end{array}$ \\
\hline 8 & $\begin{array}{l}\text { 8.2. Requirements for products } \\
\text { and services } \\
8.3 \text { Design and Product } \\
\text { Improvements } \\
8.4 \text { Product and Services } \\
\text { External Control }\end{array}$ & $\begin{array}{l}\text { 1. Limited of resources, there is no work standard } \\
\text { regarding on product and job desk itself. } \\
\text { 2. This SME use make to order method, it could not } \\
\text { handle big quantity order so lack of time to fulfill } \\
\text { the order } \\
\text { 3. There is no innovation and improvement toward } \\
\text { their product } \\
\text { 4. Less of promotion }\end{array}$ \\
\hline 9 & $\begin{array}{l}\text { 9.1 Monitoring, measurement, } \\
\text { analysis and evaluation } \\
9.2 \text { Internal Auditing }\end{array}$ & $\begin{array}{l}\text { 1. There is no specific work that has to monitor. } \\
\text { 2. Less of work control, there is no certain procedure } \\
\text { to make products } \\
\text { 3. Do not use personal protective equipment in } \\
\text { making products }\end{array}$ \\
\hline 10 & $\begin{array}{l}\text { 10.2 Incompatible and } \\
\text { corrective action } \\
10.3 \text { Continuous improvement }\end{array}$ & $\begin{array}{l}\text { 1. There is no exact procedure so it is not known } \\
\text { whether the work process is in accordance with } \\
\text { the procedure } \\
\text { 2. It has no desire to do continuous improvement }\end{array}$ \\
\hline
\end{tabular}

\subsection{Improvement Suggestion}

SME Aldin Natural Home needs commitment and effort from management in order to it could improve quality management system to get ISO 9001:2015 certifications. For clause 4, context of organization, SME Aldin Natural Home should give training for top management to improve their quality in analysis related issues to minimize repeated problems. Also, for employee, they give knowledge about how to important increasing quality, how strategy to reach it. Improvement suggestions for clause 5 are doing management observation and giving relevant assignment. With those recommendations, top management has an authority and responsibility and ensures each process done according to procedure. While, for clause 6, SME Aldin Natural Home need give training about risk 
management and review company goals to identify risk and take an action to prevent risk. Clause 7, about support, the SME should improve internal communication, make clear document and also add resources. It would overcome problem in limited time and knowledge and support for auditing. Increasing promotion is becoming one of suggestion that recommended for solving clause 8. Also, to overcome problem in clause 9, performance evaluation, the SME Aldin Natural Home need making assessment form and quality internal audit to ease evaluation process and further improvement and to assess whether product quality is increasing or decreasing. Last, for clause 10, analysis of profit increment and defect analysis are needed to measure whether work procedure is efficient or not. In addition, from those improvement suggestions, the efficient procedure can be assessed through quantity of defect.

\section{Conclusions}

Based on assessment results, SME Aldin Natural Home is in range 14\% to 29\%. The details are as follows context of the organization $25 \%$, leadership $27 \%$, planning $20 \%$, support $28 \%$, operation $29 \%$, performance evaluation $14 \%$ and improvement $20 \%$. Therefore, it needs to understand and review of implementation of ISO 9001:2015 because there are many lacks of standard.

There are several obstacles that faced in each clause ISO 9001:2015. In clause 4, lack of understanding and there are no readiness to implement ISO 9001:2015. Clause 5 has difficulty on lack of commitment and lack of division of work. Next, clause 6, there is no planning to prevent risk. In clause 7 , it is limited time and facilities. Then, clause 8 , it is limited on resources and less of promotion. Clause 9 has problems on less controlling in production process and last, clause 10 , it found less of knowledge and no desire to do continuous improvement.

In order to overcome the obstacles, there is several improvement suggestions related on ISO 9001:2015 clauses SME Aldin Natural Home. Clause 4, it is giving training for top management and employees. Clause 5, do reviewing management and making suitable task. In clause 6, giving risk management training. Clause 7, there is improving internal communication, making clear document and adding resources. In clause 8 , increasing promotion and making clear procedure. Next, clause 9, there is making assessment form and making quantity internal audit. Last clause 10, do profit increment and defect analysis.

\section{References}

1. H. P. Yaya, L., F. Marimon, and M. Casadesus, Ind. Manage. Data Syst. 111, 1194 (2011)

2. H. P. Yaya, L., F. Marimon, and M. Casadesus, Ind. Manage. Data Syst. 113, 1206 (2013)

3. B. Manders, H.J. de Vries, and K. Blind, Technovation 48, 41 (2016)

4. V. Gaspers, Gramedia Pustaka Utama (2001)

5. J.P. Wilson and L. Campbell, J. Knowl. Manag. 20, 829 (2016)

6. H. Karahalios, Safety Sci. 63, 104 (2014)

7. D. Hoyle, Rout. (2017) 